\title{
On the projected increase of Sahel rainfall during the late rainy season
}

\author{
Paul-Arthur Monerie, ${ }^{\text {a* }}$ Michela Biasutti ${ }^{\mathrm{b}}$ and Pascal Roucou ${ }^{\mathrm{a}}$ \\ ${ }^{a}$ Centre de Recherches de Climatologie (CRC), University of Burgundy, Dijon, France \\ ${ }^{\mathrm{b}}$ Lamont-Doherty Earth Observatory, Columbia University, Palisades, NY, USA
}

\begin{abstract}
Thirteen CMIP5 models are used to analyse changes in climate over the West African monsoon region between the near future (2031-2070 under the RCP4.5 emission scenario), and a control period (1960-1999 under the historical emission scenario), with a focus on the late rainy season. The monsoon circulation is projected to strengthen and to shift northward leading to more rainfall during the Sahelian season. The results show an increase of the Rainfall amounts in September-October and a delay in the monsoon withdrawal. The increased moisture that fuels the rainfall anomalies is associated with an increase in moisture flux convergence and with local moisture recycling. The moisture transport dominates the water budget change in September while the local recycling is prominent in October. The delay in monsoon withdrawal, although expected from the increase in rainfall in September-October, is not strongly correlated with the size of the monthly anomalies.
\end{abstract}

KEY WORDS climate change; Sahel; CMIP5; delay

Received 29 July 2015; Revised 3 December 2015; Accepted 4 December 2015

\section{Introduction}

Monsoon circulations are linked to the seasonal cycle of solar heating and to differences in thermal inertia between land and ocean that establish a land-sea temperature and moist static energy gradient (Webster et al., 1998; Nie et al., 2010). They are associated with a global-scale persistent atmospheric overturning circulation (Trenberth et al., 2000). Following the migration of the solar heating maximum, tropical rainy seasons occur in May-September in the Northern Hemisphere and in November-March in the Southern Hemisphere. During these periods, moist convection increases, becomes more organized and brings abundant precipitation, sustaining widespread rainfed agriculture.

Observations indicate that the onset of the West African monsoon (WAM) occurs at the end of June (Sultan and Janicot, 2000, 2003; Fontaine and Louvet, 2006) as an abrupt shift of the rainfall maximum from the Guinean coast to the Sahel, the 'monsoon jump' (Sultan and Janicot, 2003; Hagos and Cook, 2007). The dynamic of the onset has been linked to the heat low (Sultan and Janicot, 2003; Lavaysse et al., 2009), the cold-tongue set up (Okumura and Xie, 2004; Caniaux et al., 2011) and to complex interactions among convective processes in the InterTropical Convergence Zone (ITCZ), circulation associated with local topography and African easterly jet (AEJ) dynamics (Sultan and Janicot, 2003). The demise occurs between

\footnotetext{
* Correspondence to: P.-A. Monerie, Centre de Recherches de Climatologie, CRC, UMR 6282, CNRS/Université de Bourgogne, 6 Boulevard Gabriel, FR-21000 Dijon, France. E-mail: pmonerie@gmail.com
}

September and November in West Africa (Liebmann et al., 2012): first in the Sahel and then in Guinea. An early (late) demise has been associated with an anomalously strong (weak) North Atlantic subtropical high (NASH), which favours the increase (decrease) of the southerly moisture flux leading to an increase (decrease) of the moisture flux convergence over the Sahel (Zhang and Cook, 2014).

A positive rainfall trend from the nineties to present has been described as a 'recovery' of rainfall over the Sahel (Nicholson, 2005; Lebel and Ali, 2009) following the drought of the seventies and eighties. Recently Sanogo et al. (2015) have shown that the increase of rainfall over the Sahel during the period 1980-2010 is more prominent during the heart and the end of the season in August-September-October. In the context of climate change, a consensus is emerging to indicate similar changes. The most recent studies, based on multimodel analysis, show that the summer precipitation is projected to increase over the central Sahel and to decrease over the western Sahel (Monerie et al., 2012; Biasutti, 2013; James et al., 2015). The monsoon strengthening has been associated with an increase of the land-sea temperature gradient (as described by Haarsma et al., 2005), of the cross-equatorial SST gradient in the tropical Atlantic (Hoerling et al., 2006) and of the gradient between the extratropical Atlantic and the Tropics (Park et al., 2015). This gradient would also be modified by anomalies in the eastern tropical Atlantic that reflect a change in the Atlantic circulation (Kröger et al., 2005; Grist et al., 2010; Servain et al., 2014).

The more limited rainfall decrease over the western Sahel has been associated with an anomaly of subsidence 
Table 1. Names, references and grid resolutions of the 13 CMIP5 models used in this study.

\begin{tabular}{|c|c|c|c|}
\hline Models & References & Institution & Resolution \\
\hline canesm2 & Chylek et al. (2011) & Canadian Centre for Climate Modelling and Analysis (Canada) & $128 \times 64 \times 22$ \\
\hline cnrm_cm5 & Voldoire et al. (2013) & Centre National de Recherches Météorologiques (France) & $256 \times 128 \times 17$ \\
\hline csiro_mk3_6_0 & Rotstayn et al. (2010) & CSIRO Atmospheric Research (Australia) & $192 \times 93 \times 18$ \\
\hline giss_è2_r & Shindell et al. (2013) & Goddard Institute for Space Studies (USA) & $144 \times 89 \times 17$ \\
\hline hadgem 2 es & Collins et al. (2011) & Met Office (UK) & $192 \times 144 \times 17$ \\
\hline inmem4 & Volodin et al. (2010) & Institute for Numerical Mathematics (Russia) & $180 \times 120 \times 17$ \\
\hline ipsl_cm5a_lr & Dufresne et al. (2013) & Institut Pierre-Simon Laplace (France) & $96 \times 96 \times 17$ \\
\hline mri_cgcm 3 & Yukimoto et al. (2012) & Meteorological Research Institute (Japan) & $320 \times 160 \times 23$ \\
\hline bcc_csm1-1 & Xiao-Ge et al. (2012) & Beijing Climate Center (China) & $128 \times 64 \times 17$ \\
\hline bnu_esm & $\begin{array}{l}\text { More informations on the } \\
\text { websites: } \\
\text { http://esg.bnu.edu.cn/ } \\
\text { BNU_ESM_webs/htmls/ } \\
\text { index.html and } \\
\text { http://esg.bnu. } \\
\text { edu.cn/BNU_ESM_webs/ } \\
\text { htmls/index.html }\end{array}$ & Beijing Normal University (China) & $128 \times 64 \times 17$ \\
\hline gfdl_esm2m & Dunne et al. (2012) & Geophysical Fluid Dynamics Laboratory (USA) & $144 \times 91 \times 17$ \\
\hline miroc_esm & Watanabe et al. (2011) & Center for Climate System Research Institute (Japan) & $128 \times 64 \times 35$ \\
\hline noresm1_m & Bentsen et al. (2012) & The Norwegian Climate Centre (Norway) & $144 \times 96 \times 17$ \\
\hline
\end{tabular}

and a strengthening of the AEJ (Monerie et al., 2012; James et al., 2015).

Climate change has also been shown to impact the WAM during the demise months, in SO (September-October): the entire Sahel is projected to become wetter in response to increase greenhouse gases (Biasutti and Sobel, 2009; Wang and Alo, 2012; Biasutti, 2013; Seth et al., 2013). Using general circulation model (GCM) and regional climate models (RCMs), Vizy and Cook (2012) and Vizy et al. (2013) have found that the increase in seasonal total Sahel rainfall follows from more intense rainfall, and no appreciable change in the length of the rainy season.

The aim of this study is to address two main questions: (1) Is a consensus on SO Sahel rainfall emerging around the middle of this century in a reduced-emission scenario? (2) What are the mechanisms responsible for the changes?

This article is organized as follows. Data and methods are presented in Section 2. This study focuses on rainfall anomalies in Section 3 and on the associated moisture flux changes in Section 4. Section 5 allows an analysis of the changes occurring specifically in September and October. We address the question of the demise date in Section 6. Section 7 concludes.

\section{Data and method}

\subsection{Climate change analysis}

We select 13 CMIP5 model outputs downloaded from the Program For Climate Model Diagnosis and Intercomparison (PCMDI) server (http://pcmdi9.1lnl.gov/esgf-web-fe/) and used in the fifth phase of the Coupled Model Intercomparison Project CMIP5 (Taylor et al., 2012): names, references and resolutions are given in Table 1.
The present climate is defined as mean of the historical simulation over the period 1960-1999 (and is noted 'CTRL' for the control simulation), the future climate is defined as the Representative Concentration Pathway (RCP) 4.5 simulation from 2031 to 2070 (and is noted 'FTR' for the future simulation). RCP4.5 is a medium-low emission scenario reaching about $4.5 \mathrm{~W} \mathrm{~m}^{-2}(\sim 540 \mathrm{ppm}$ $\mathrm{CO}_{2}$ ) in year 2100 (Meinshausen et al., 2011; Thomson et al., 2011). According to Rogelj et al. (2012), the RCP4.5 is comparable to the Special Report on Emissions Scenarios (SRES) B1 with similar $\mathrm{CO}_{2}$ concentrations; the ensemble median temperature rises quickly until mid-century, more slowly afterwards and exceeds $+2{ }^{\circ} \mathrm{C}$ warming after 2100. Climate change effects are computed as the differences between the mean FTR and the mean CTRL climates. As the time evolution of monsoonal rainfall is linked to Sea Surface Temperature (SST) variability, including the Atlantic multidecadal oscillation, the Pacific decadal oscillation, the interdecadal Pacific oscillation and SSTs in the Gulf of Guinea, the results may be influenced by the SST decadal variability in a warming world. To avoid this bias, this study uses 40-years periods and a multimodel ensemble. Decadal and multidecadal variability are thereby in partly smoothed. The multidecadal periodicity of the SSTs (such as the interdecadal Pacific oscillation) can impact the Sahel rainfall low-frequency variability (Villamayor and Mohino, 2015), but the multimodel average ensures that this variability is also smoothed because occurring on different timings for each model.

The multimodel analysis minimizes biases (Lambert and Boer, 2001; Phillips and Gleckler, 2006; Randall et al., 2007; Gleckler et al., 2008; Pincus et al., 2008; Reichler and Kim, 2008; Pierce et al., 2009), but several errors common to models can remain, such as a poor cold tongue simulation (Richter and Xie, 2008) in the Gulf of Guinea. However, this method appears to be better than the choice 
of a 'best model' (Knutti et al., 2010), because model selection is never evident and depends on the scope of each study (Santer et al., 2009).

The multimodel approach assumes that the models used are independent, avoiding any over-representation of one type of model configuration. Thus, we chose only one model per climate centre (13 models) and one simulation per model to give the same weight to each climate centre and to maximize model independency (as suggested by Knutti et al., 2010; Masson and Knutti, 2011; Pennell and Reichler, 2011). All fields are interpolated on the same $2.5 \times 2.5^{\circ}$ resolution. We complement the 'FTR' minus 'CTRL' difference maps with maps of occurrences based on the 'one model, one vote' concept proposed by Santer et al. (2009) and used by Fontaine et al. (2011) and Monerie et al. (2012, 2013). This metric indicates whether the signal is due to several outlier models or to the majority of models.

\subsection{Moisture flux decomposition}

In this article, the surface moisture fluxes are broken into its mean circulation dynamics (MCD) and the thermodynamic $(\mathrm{TH})$ components:

$$
\begin{aligned}
\delta_{\mathrm{TH}} & =\overline{\vec{u}}_{\mathrm{CTRL}} \overline{\delta q} \\
\delta_{\mathrm{MCD}} & =\overline{\delta_{\vec{u}}} \overline{q_{\mathrm{CTRL}}}
\end{aligned}
$$

where,

$$
\delta(.)=(.)_{\mathrm{FTR}}-(.)_{\mathrm{CTRL}}
$$

is the RCP-historical change, bars are the monthly means and subscripts ${ }_{\text {FTR }}$ and ${ }_{\text {CRL }}$ indicate the FTR and CTRL period values of the arbitrary quantity in parentheses. The decomposition is performed for the zonal $(u)$ and meridional $(v)$ components of the wind $(\vec{u})$.

This decomposition is inspired by Seager et al. (2010), but it is limited to low-level fields, where moisture flux is greatest.

\subsection{Demise date}

The withdrawal of the monsoon is more abrupt than the set-up which is marked by active and break phases (Louvet et al., 2003). Various methods are employed to detect onset/demise dates. Here we follow the methodology developed by Liebmann et al. (2012) based on the difference between the daily precipitation and the long term annual mean daily average.

For each year and grid point, the precipitation annual mean is computed and subtracted from the raw daily value of precipitation to give an accumulation anomaly $(A)$ as a function of calendar day

$$
A(\text { days })=\sum_{n=1}^{\text {days }}(R(n)-(\bar{R}))
$$

where $R(n)$ is the daily precipitation and $\bar{R}$ is the annual average. The day at which the accumulation anomaly

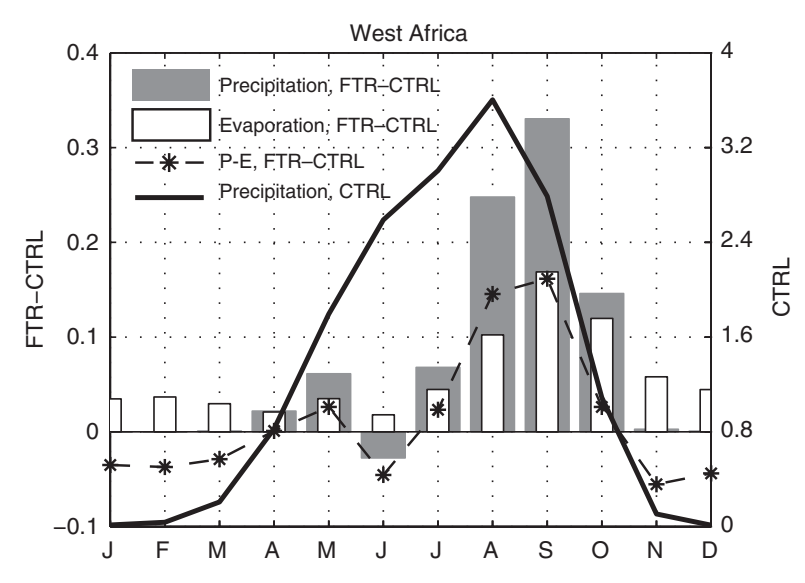

Figure 1. Rainfall amounts evolutions $\left(\mathrm{mm} \mathrm{day}^{-1}\right)$ from January to December averaged over (a) the Sahel $\left(10^{\circ} \mathrm{W}-10^{\circ} \mathrm{E} ; 10^{\circ}-20^{\circ} \mathrm{N}\right)$ (the two domains are represented within Figure 2(a)). The mean CTRL climate is represented by a continuous black line (right abscissa) and the FTR minus CTRL differences by the bars for precipitation (grey bars) and evaporation (white bars) (left abscissa). The FTR-CTRL precipitation minus evaporation $(\mathrm{P}-\mathrm{E})$ result is represented with discontinuous lines and stars (left abscissa).

reaches its maximum is the day of demise of the rainy season. This method is more appropriate than the use of a simple threshold because there are large variations in the rainfall values from one model to another.

\section{Rainfall amount and atmospheric circulation changes in September-October}

Figure 1 displays the monthly mean rainfall climatology simulated for the Sahel $\left[10^{\circ} \mathrm{W}-10^{\circ} \mathrm{E} ; 10^{\circ}-20^{\circ} \mathrm{N}\right]$ (see the box in Figure 2(a)) in the CTRL simulation (continuous black line), along with the precipitation, the evaporation, and precipitation minus evaporation $(\mathrm{P}-\mathrm{E})$ differences between the FTR and CTRL periods (grey bars, white bars and stars). In the FTR period, the Sahel is projected to become wetter than CTRL from July to October: during the core of the rainy season and during the demise months. This is associated with an increase in moisture flux convergence (positive values of the $\mathrm{P}-\mathrm{E}$ change). In October, the large evaporation anomalies suggest that local water recycling could play a key role in producing a wetter late season. More precipitation during the last months of the monsoon is consistent with the literature as reported by Kitoh et al. (2013) and Lee and Wang (2014) for the global monsoon and by Biasutti and Sobel (2009), Biasutti (2013) and Seth et al. (2013) for the WAM. The increase of rainfall at the end of the northern tropical rainy season is the focus of this work and may denote a delay in the monsoon withdrawal.

The increase of precipitation in September-October (SO) is significant over the entire Sahel (Figure 2(a)) and robust (it is reproduced by a large majority of the models, up to 10 models out of 13; Figure 2(b)). A maximum in precipitation anomaly is located around the Greenwich meridian (box in Figure 2(a); $10^{\circ} \mathrm{W}-10^{\circ} \mathrm{E} / 10^{\circ}-20^{\circ} \mathrm{N}$ ). This rainfall increase is over and northward of the mean 
(a)
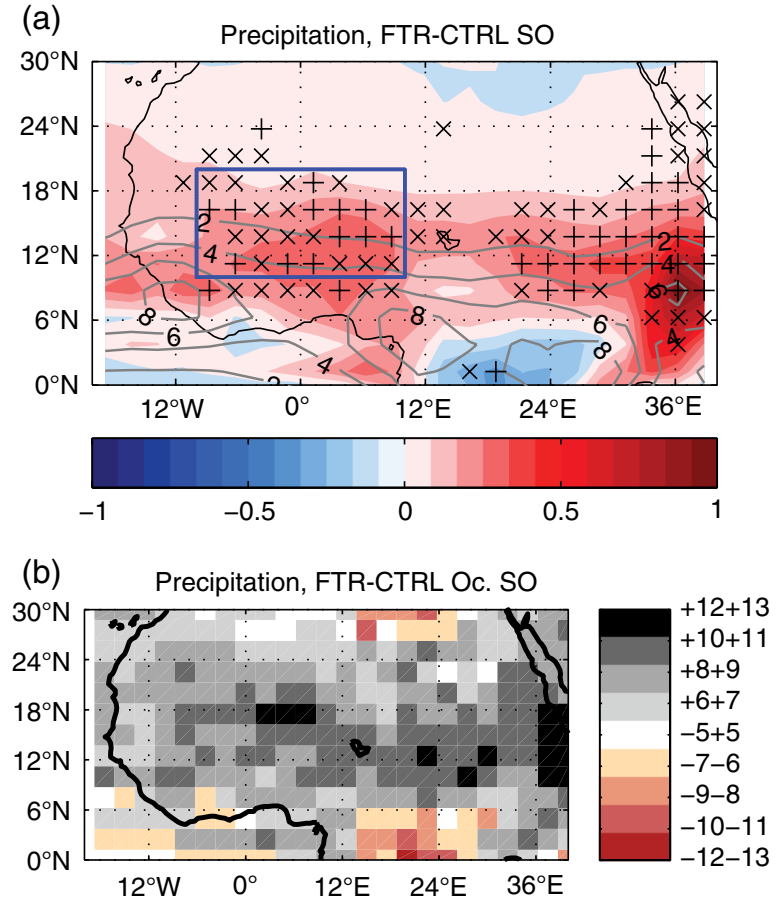

Figure 2. (a) Mean SO rainfall amounts $\left(\mathrm{mm} \mathrm{day}^{-1}\right)$ over the CTRL period (grey lines) and for the FTR-CTRL differences (shadings). The values judged significant with a Student's $t$-test at $p=0.05 \quad(p=0.10)$ are marked by a plus (cross). (b) Occurrence map: a value of +11 or $+12(-11$ or -12$)$ means that 11 or 12 models are in accordance with a positive (negative) change in multimodel differences. Sixteen CMIP5 models have been used.

rain band in the CTRL simulation (continuous grey lines) and represents a strengthening and a northward shift of the monsoon system.

This is consistent with the anomalies in low-level $(925-850 \mathrm{hPa})$ winds, which are located between $10^{\circ} \mathrm{N}$ and $20^{\circ} \mathrm{N}$, north of the climatological southwesterlies converging into the Sahel (Figure 3(a)). It is well known that a northward position of the AEJ and a strengthening of the Tropical Easterly Jet (TEJ) are related to wet years (Grist and Nicholson, 2001). At mid-level, there is no significant change of the AEJ speed and position (located between 700 and $600 \mathrm{hPa}$ and from $5^{\circ}$ to $15^{\circ} \mathrm{N}$ in the mean CTRL period). The TEJ seems to move southward (see the negative anomalies between $5^{\circ} \mathrm{S}$ and $5^{\circ} \mathrm{N}$ at $250 \mathrm{hPa}$ ) but it is not well defined in the CTRL period. A significant upper-level easterly anomaly at $25^{\circ} \mathrm{N}$ could be linked to the northward shift of the jet shown by Yin (2005).

The main changes of the zonal winds are thus the strengthening of the low-level south-westerlies and a weakening of the subtropical westerly jet; both are reproduced by at least ten models (Figure 3(c)).

Along with these winds, the monsoon cell moves northward and West Africa experiences more subsidence from $5^{\circ}$ to $15^{\circ} \mathrm{N}$ and more ascent north of $15^{\circ} \mathrm{N}$ and south of $25^{\circ} \mathrm{N}$ (Figure 3(b)). The negative values of the omega anomalies are significant (and denote by convention more ascending motions) and robust (Figure 3(d)). Deep ascending anomalies extending from 925 to $200 \mathrm{hPa}$ are co-located with the increase in rainfall up to $20^{\circ} \mathrm{N}$. At low-level, the omega anomalies indicate a northward shift of the monsoon flow pushing the confluence boundary and the shallow dry ascent to $23^{\circ} \mathrm{N}$.

The increase in rainfall amounts in SO is associated with the strengthening and northward shift of the monsoon circulation. What is the source of moisture for the additional rainfall? This question is explored in the next section.

\section{Changes in moisture supply}

Evaporation anomalies are positive year round (Figure 1; white bars) but are largest during the late months of the rainy season because evaporation anomalies are in large part a consequence of the accumulated rainfall anomalies. Evaporation is moisture-rather than energy-limited in the semi-arid Sahel (Cook et al., 2014). The P - E change (Figure 1; stars) indicates an increase of moisture convergence over the Sahel during the rainy season, with largest values in August and September.

Kitoh et al. (2013) showed that projections of rainfall surplus in the global monsoon area are mainly due to increases in specific humidity, which produces an increase in moisture flux convergence, even in the face of weakening circulations. This explanation does not seem to hold for the WAM, as the simulations project large changes in the regional circulation and indeed a strengthening of the monsoon flow and of deep ascent.

Figure 4 shows the maps of wind and sea level pressure (Figure 4(a)), moisture and moisture flux at $825 \mathrm{hPa}$ (Figure 4(b)) for the mean CTRL SO period. In SO, the main source of moisture for the monsoon rain is the Mediterranean Sea and the North Atlantic Ocean with northerlies (Figure 4(a)) converging moisture over West Africa (Figure 4(b)).

Figure 4(c) and (d) show SO FTR-CTRL differences of sea-level pressure and winds (Figure 4(c)), and specific humidity and moisture flux (Figure 4(d)) at $825 \mathrm{hPa}$. The Sea Level Pressure (SLP) anomalies show anticyclonic anomalies over mid-latitude continental Europe and the western Mediterranean region, corresponding to a northward shift of the NASH (Figure 4(c) and (e)). Over Africa, cyclonic anomalies indicate a deeper heat low (Figure 4(c)). The anomalous pressure gradients favour significant increases in the northerlies and southerlies converging in the northern Sahel (Figure 4(c)). As expected from the global temperature increase, the specific humidity is higher over the entire domain (Figure 4(d)). The anomalous moisture flux converges moisture over the Sahel mainly from the eastern Mediterranean Basin. These changes are significant and reproduced by a large majority of models (Figure 4(f) and (g)).

Examining the components of the moisture fluxes shows how a strengthening of the winds and increases in specific humidity affect the $\mathrm{P}-\mathrm{E}$ changes. The surface moisture flux anomalies are broken down into a component due to changes in monthly means wind (the MCD) and a component due to the monthly mean changes in surface specific 
(a)

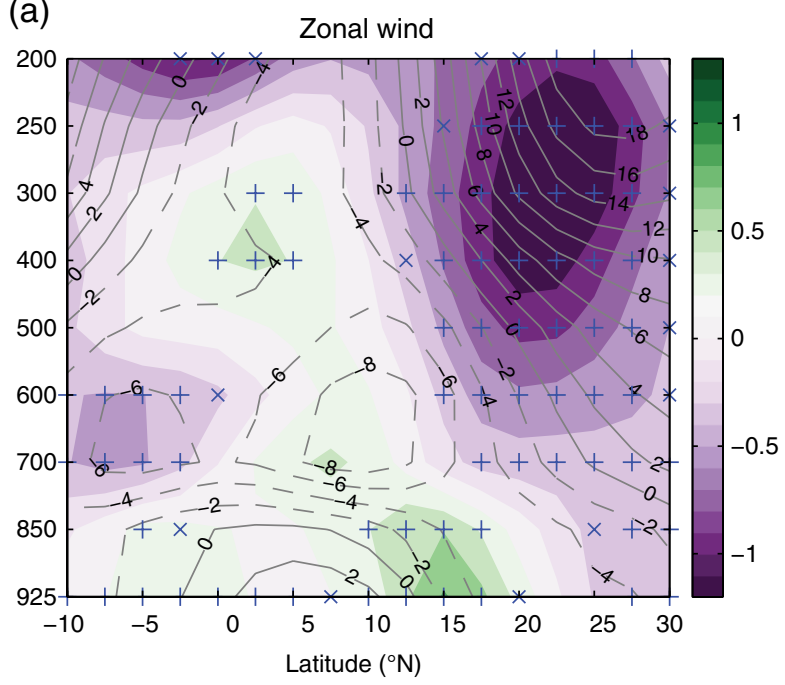

(c)

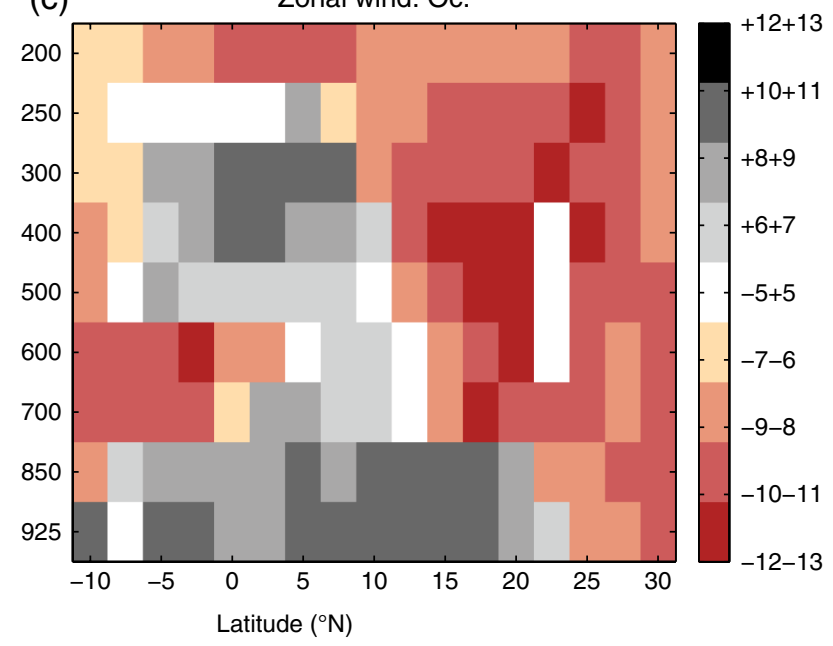

(b)

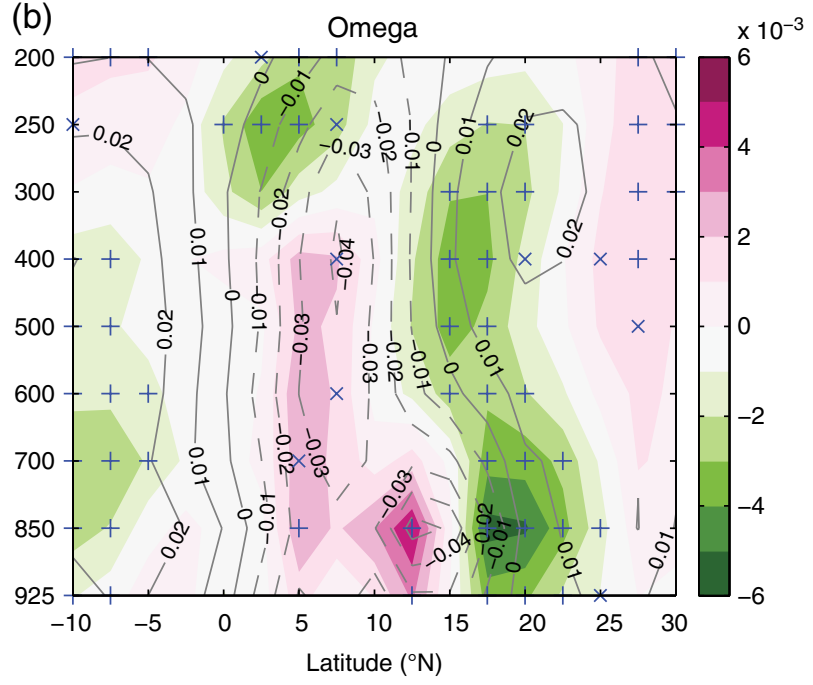

(d)

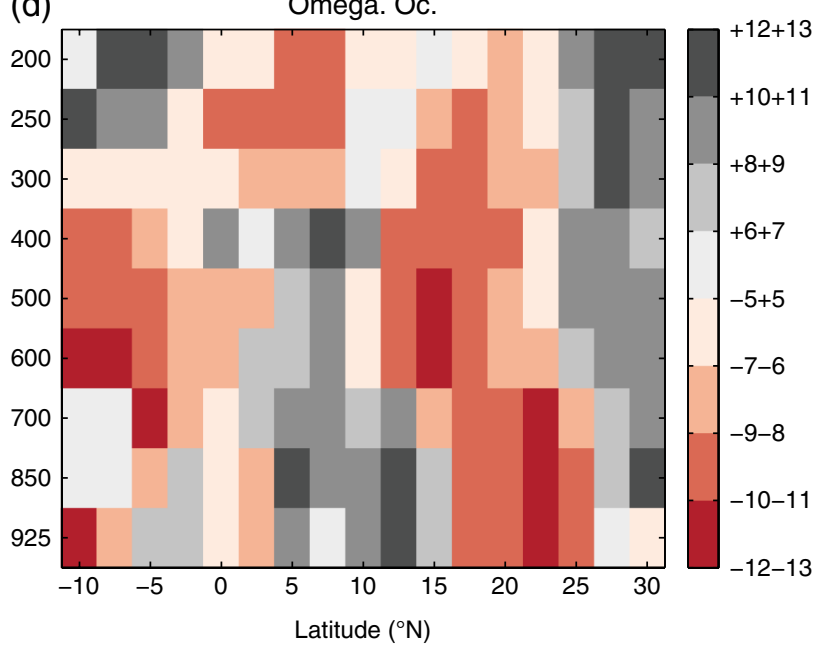

Figure 3. Latitude-height cross section (average from $10^{\circ} \mathrm{W}-10^{\circ} \mathrm{E}$ ) of (a) zonal winds $\left(\mathrm{m} \mathrm{s}^{-1}\right)$ and (b) omega (hPa). The mean CTRL is displayed with grey contours and the FTR-CTRL change with shadings. The values judged significant with a Student's $t$-test at $p=0.05$ are marked by a plus. Maps of occurrences (number of models) of the FTR minus CTRL differences of (c) zonal wind and (d) omega.

humidity $(\mathrm{TH})$ at $825 \mathrm{hPa}$. The results are displayed in Figure 5.

The dynamic and TH components are of the same magnitude (Figure 5(a) and (b)). The moisture flux change associated with the TH is more important in northern Sahel (at $20^{\circ} \mathrm{N}$ ) and MCD anomalies are associated with more inflow from the tropical Atlantic south of the Sahel $\left(12^{\circ} \mathrm{N}\right)$ (Figure 5(a) and (b)). The northward shift of the monsoon is therefore dominated by the change in dynamic but a large part of the moisture increase is due to the strengthening of the northerlies. The strengthening of the moisture flux associated with the MCD and TH is robust over the Sahel (Figure 5(c) and (d)).

We can thus draw the conclusion that the late monsoon season is projected to be wetter (Figure 2(a)) due to increased moisture fluxes (Figure 4(d)) associated with the global temperature rising and to a northward shift of the monsoon system and of the North Atlantic high (Figure 4(b)). This is a classic view of the climate change impact on the WAM that can also be drawn for the JAS time-period (Maynard et al., 2002; Monerie et al., 2012, 2013; James et al., 2015, among others, and suggested in Figure 1). The aim of this study is, however, to analyse the changes specific to the late monsoon season. Figure 1 shows stronger increases of moisture flux convergence $(\mathrm{P}-\mathrm{E})$ in September than in October suggesting larger role for dynamics in September. Such differences are analysed in the next section.

\section{September and October changes}

We compute the S-JJASO and O-JJASO anomalies to stress the particularity of each month with respect to the extended rainy season. We define

$$
\mathrm{M}-\mathrm{JJASO}=\mathrm{FTR}_{(\mathrm{M}-\mathrm{JJASO})}-\mathrm{CTRL}_{(\mathrm{M}-\mathrm{JJASO})}
$$

where $\mathrm{M}$ is the month we are looking for (i.e. September or October), FTR $_{(\mathrm{M}-\mathrm{JJASO})}$ and CTRL $(\mathrm{M}-\mathrm{JJASO})$ are the seasonal means, respectively, for the FTR and CTRL periods. 
(a)

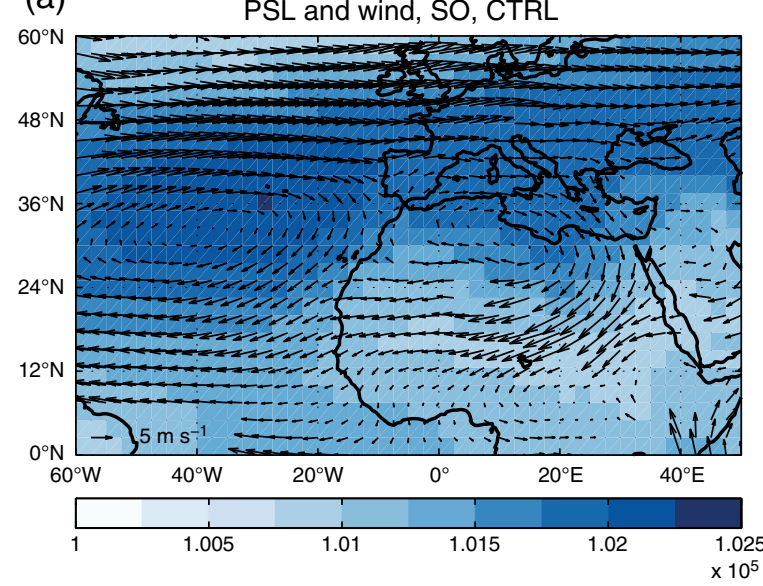

(c)

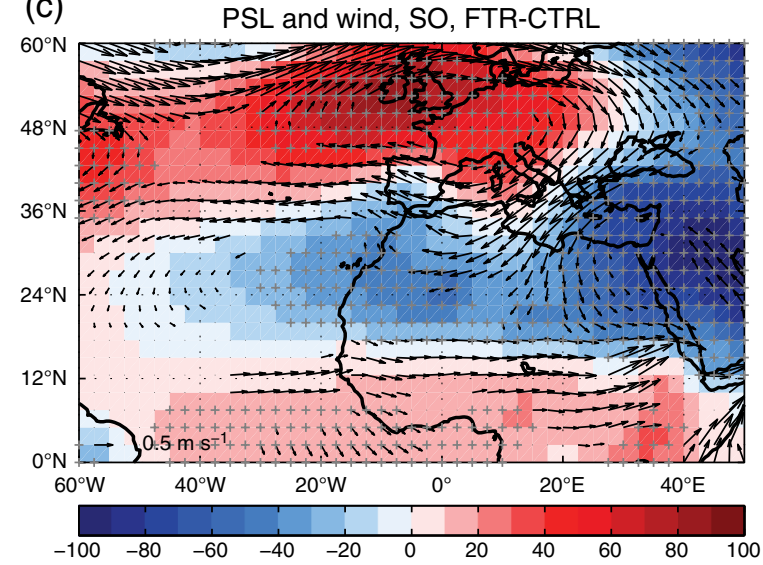

(e)

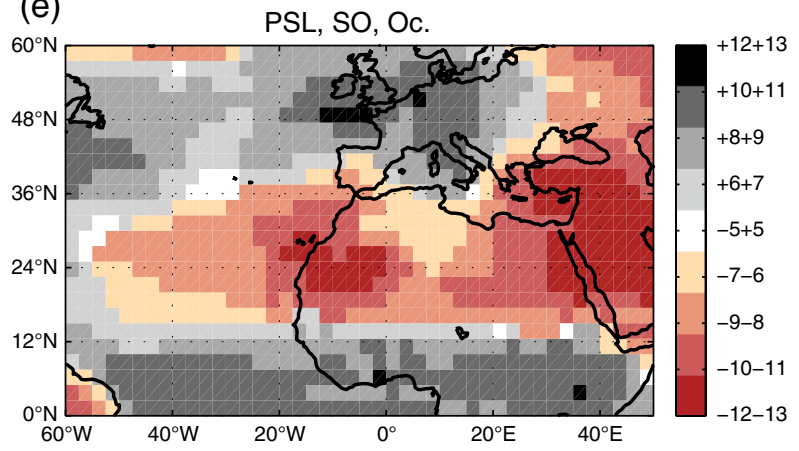

(b) Specific humidity and moisture flux, SO, CTRL

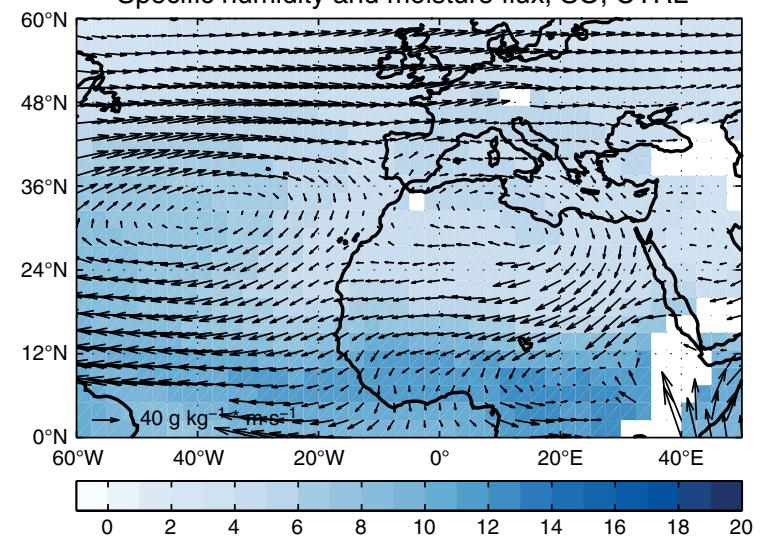

(d) Specific humidity and moisture flux, SO, FTR-CTRL

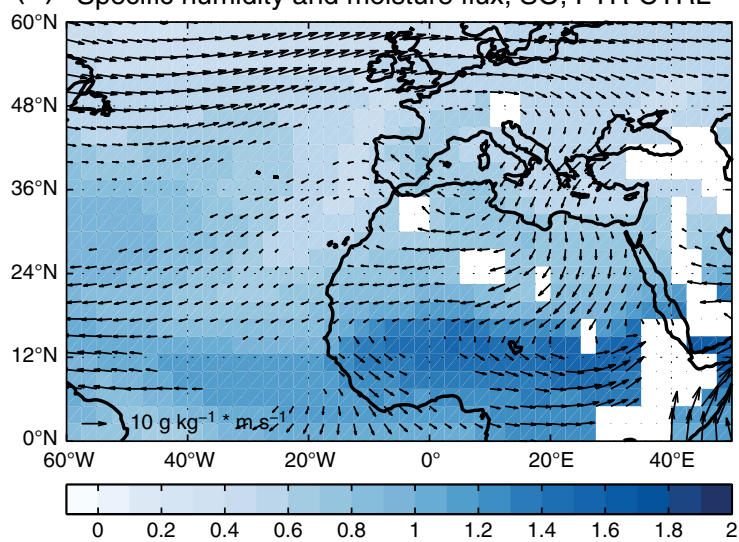

(f)

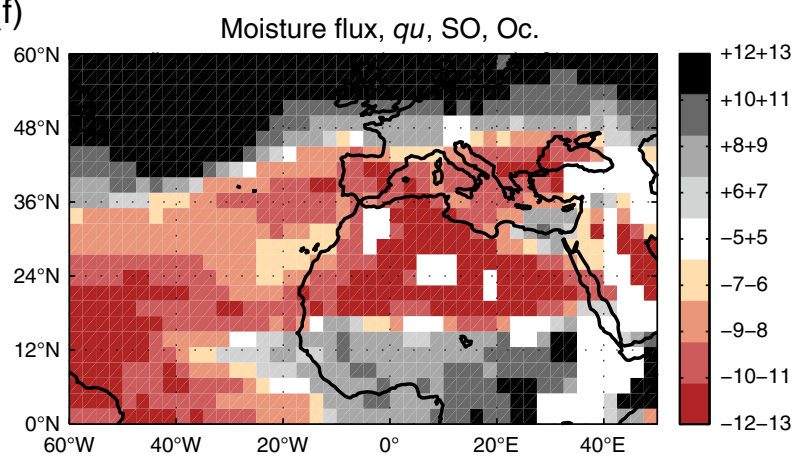

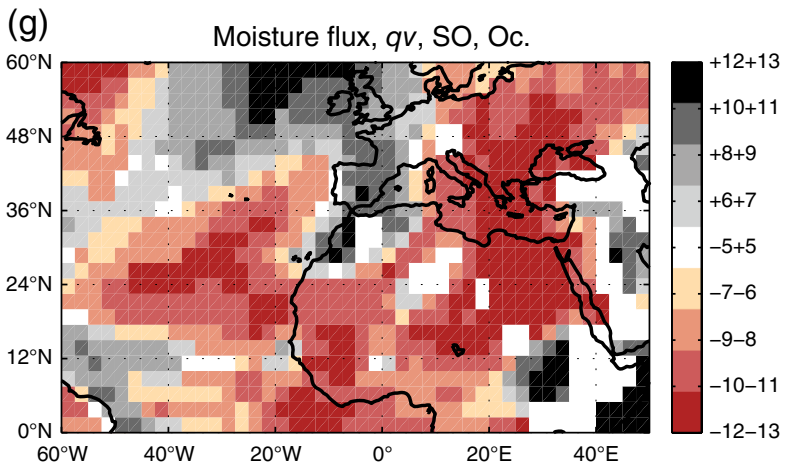

Figure 4. SO mean of (a) sea level pressure (Pa) and wind $\left(\mathrm{m} \mathrm{s}^{-1}\right)$, (b) specific humidity $\left(\mathrm{g} \mathrm{kg}^{-1}\right)$ and moisture flux $\left(\mathrm{g} \mathrm{kg}^{-1} \times \mathrm{m} \mathrm{s}-1\right)$ at $825 \mathrm{hPa}$, SO FTR-CTRL differences of (c) sea level pressure and winds, (d) specific humidity and moisture flux at $825 \mathrm{hPa}$. SLP values are shown with shadings and superimposed grey plus when the differences are significant at $p=0.05$. For more clarity, only the significant moisture flux differences are represented (vectors). Maps of occurrences (number of models) of the FTR minus CTRL differences of (e) SLP, (f) the zonal component of the moisture flux and $(\mathrm{g})$ the meridian component of the moisture flux. 
(a)

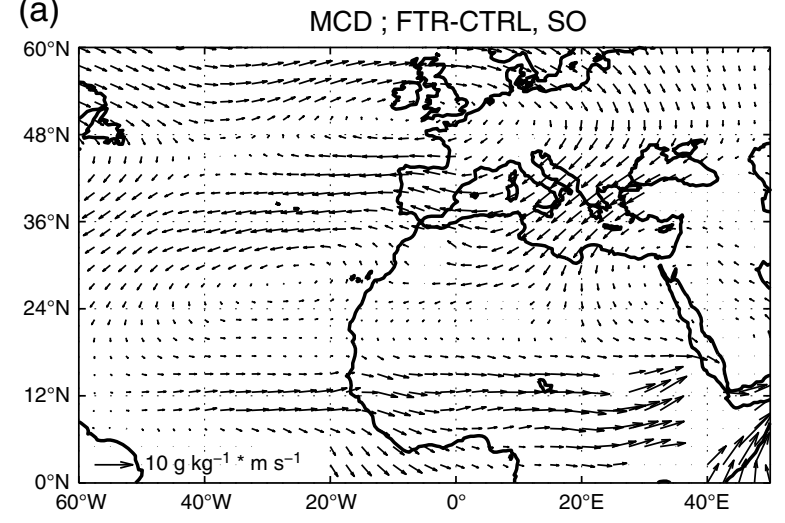

(c) MCD ; FTR-CTRL, SO; Oc. v-component

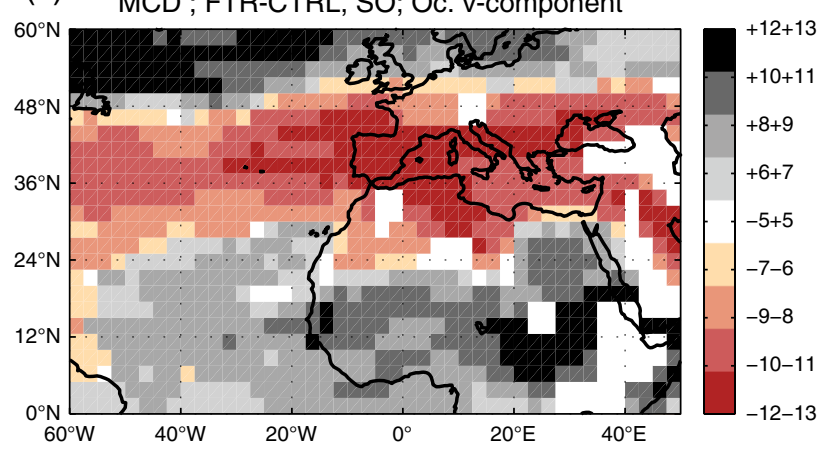

(b)

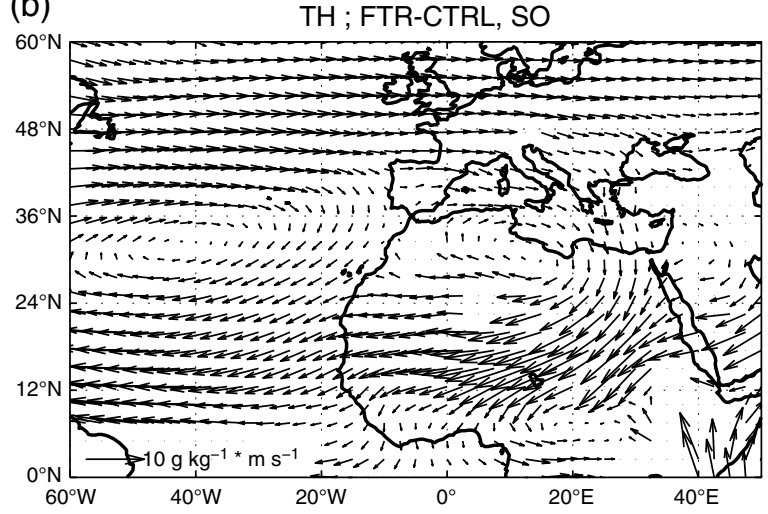

(d)

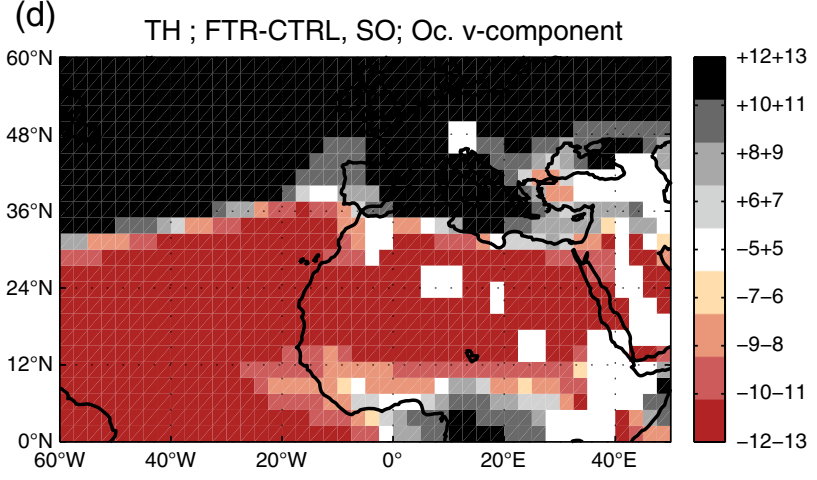

Figure 5. (a) Mean circulation dynamic (MCD) and (b) thermodynamic (TH) in SO ( $\mathrm{g} \mathrm{kg}^{-1}$ ) and at $825 \mathrm{hPa}$. Maps of occurrences (number of models) for the meridian component of the (c) MCD and (d) TH.

Please note that these anomalies are not directly comparable to the results displayed in Figures 2-5.

Figure 6 displays the S-JJASO (first column) and the O-JJASO (second column) anomalies of SLP, $825 \mathrm{hPa}$ moisture fluxes and rainfall. In September, the anomaly of SLP indicates a deeper heat low centred at $10^{\circ} \mathrm{E}$ and North of the Sahel (Figure 6(a)), although the anomaly is not significant across the ensemble. Rainfall increases in association with the anomalous northerly moisture flux (Figure 6(a) and (e)). The O-JJASO anomaly exhibits an increase in SLP over Europe and the Mediterranean and extending over the Sahara. In association with it, there is an increase in moisture flux from the eastern Mediterranean towards the Sahel (Figure 6(b) and (f)). Nonetheless, the strongest moisture flux anomaly is south of $20^{\circ} \mathrm{N}$ indicating that the moisture flux change is mainly due to local changes of moisture over the Sahel. This is consistent with Figure 1, which clearly indicates that local evaporation is the dominant contribution to the water budget change in October. Thus, rainfall increases just south of the northerly moisture flux increase (Figure 6(b))

\section{The withdrawal date of the WAM}

The increase in rainfall during September and October may denote a change in the demise date of the rainy season. As described in Section 2.3, we define the end of the monsoon as the date when daily precipitation systematically drops below its local annual mean, as described by Liebmann et al. (2012). A demise date is computed for each grid point and each model. The mean demise date of the Sahel is then obtained as the average of each demise date for each grid point covering the central Sahel (defined as in Figure $\left.2(\mathrm{a}): 10^{\circ} \mathrm{W}-10^{\circ} \mathrm{E} ; 10^{\circ}-20^{\circ} \mathrm{N}\right)$. The sensitivity to such choice is checked by using two other boxes, namely the western Sahel $\left(15^{\circ} \mathrm{W}-0^{\circ} \mathrm{E} ; 10^{\circ}-20^{\circ} \mathrm{N}\right)$ and the eastern Sahel $\left(0^{\circ}-25^{\circ} \mathrm{E} ; 10^{\circ}-20^{\circ} \mathrm{N}\right)$. For the CTRL period, the mean demise dates over the western, central and eastern Sahel are 4 October, 30 September and 22 September. These demise dates are consistent with the study of Liebmann et al. (2012) who found that the demise occurs between September and November in West Africa, and late over western than central Sahel.

The FTR minus CTRL differences are shown in Figure 7(a). Over the entire Sahel, the demise date are projected to occur several days later, denoting a delay of the rainy season withdrawal. In Figure 7(b), we plot the inter-model spread in the anomalies in demise date as a function of the SO mean change for the western, the central and the eastern Sahel. We find a weak dependence between the two quantities and a linear relationship is statistically significant only for the western Sahel. The weak relationship is especially due to anomalies in the miroc_esm, which is an outlier model for the region (Figure 7(b)). This model does simulate an increase in precipitation in SO but the increase during JAS is a lot stronger (the increase reaches $3 \mathrm{~mm} \mathrm{day}^{-1}$, i.e. ten times the multimodel change) and the shape of the accumulation 
(a)

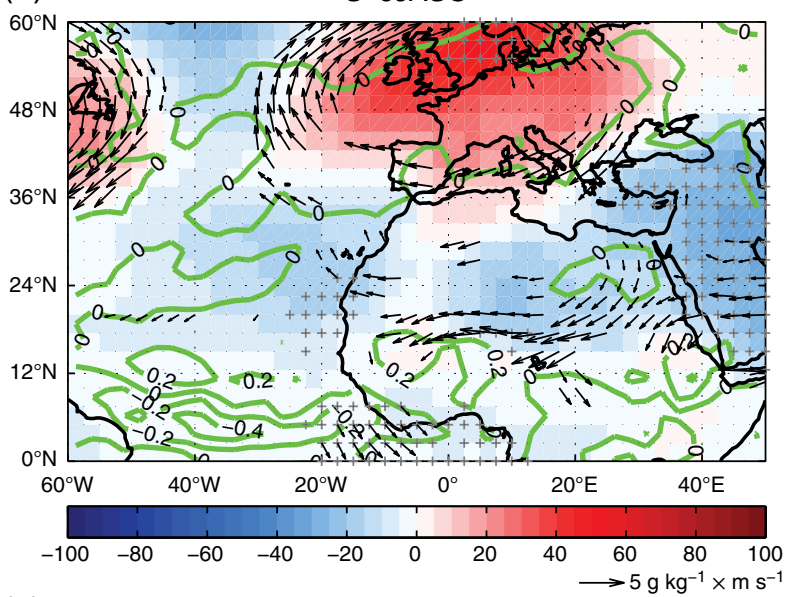

(c)

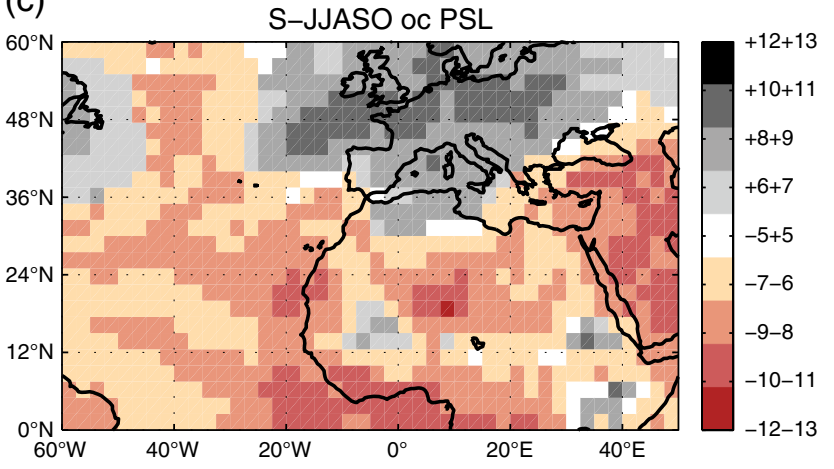

(e)

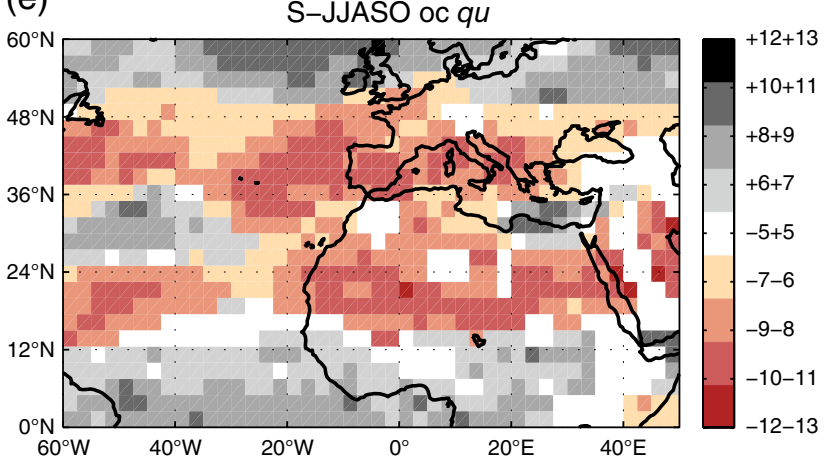

(b)

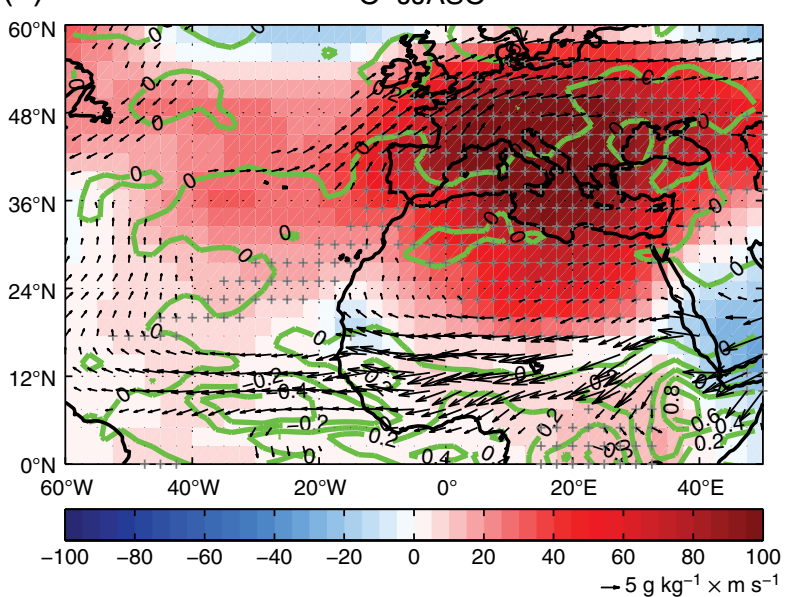

(d)

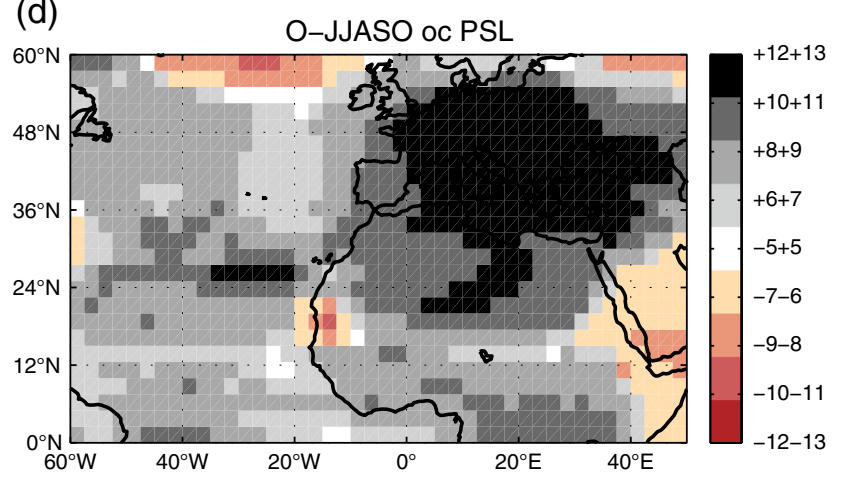

(f)

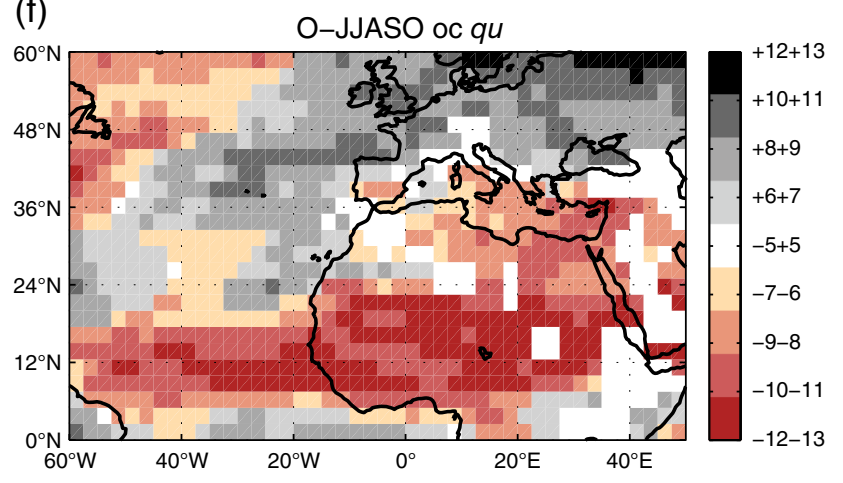

Figure 6. Moisture flux $\left(\mathrm{g} \mathrm{kg}^{-1} \times \mathrm{m} \mathrm{s}^{-1}\right.$ ) at $825 \mathrm{hPa}$, sea level pressure (Pa) and rainfall (mm day ${ }^{-1}$ ) for the FTR-CTRL (a) S-JJASO differences and (b) O-JJASO differences. SLP values are shown with shadings and superimposed grey plus when the differences are significant at $p=0.05$. For more clarity, only the significant moisture flux differences are represented (vectors). The rainfall differences are displayed with continuous lines for positive values and discontinuous lines for negative values. Maps of occurrences (number of models) of the FTR minus CTRL differences of (c) S-JJASO SLP, (d) O-JJASO SLP, (e) S-JJASO meridian component of the moisture flux and (f) O-JJASO meridian component of the moisture flux.

anomaly is not changed (not shown). A large majority of the models simulate a delayed demise date along with the increase in $\mathrm{SO}$ rainfall.

For Zhang and Cook (2014), a late demise date is associated with a weak NASH and increased southerlies while we found more rainfall during the demise months because of a local increase of moisture convergence and northerlies. These two results are not excluding each other because these mechanisms do not occurs on the same time-scale (daily in the study of Zhang and Cook, 2014 and monthly here). Moreover, our definition of the demise date differs: we chose a measure that takes into account the entire rainfall season, while they use a fixed threshold of $2 \mathrm{~mm} \mathrm{day}^{-1}$.
Our choice of how to define the demise of the rainy season has the advantage of being compatible with the coarse-resolution of our rainfall data. Yet, it is not the definition that is used on the ground: because the timing of the rainy season is tracked for agricultural purposes, the demise of the rainy season is typically defined as the cessation of the growing season (when soil moisture is so depleted that it cannot support crop growth). Following Lodoun et al. (2013), we compute the cessation date of the growing season for the CTRL and FTR periods. In the latter case, we scale the daily potential evapotranspiration to take into account the effect of higher temperature (in accordance with Scheff and Frierson, 2014, we imposed 
(a)

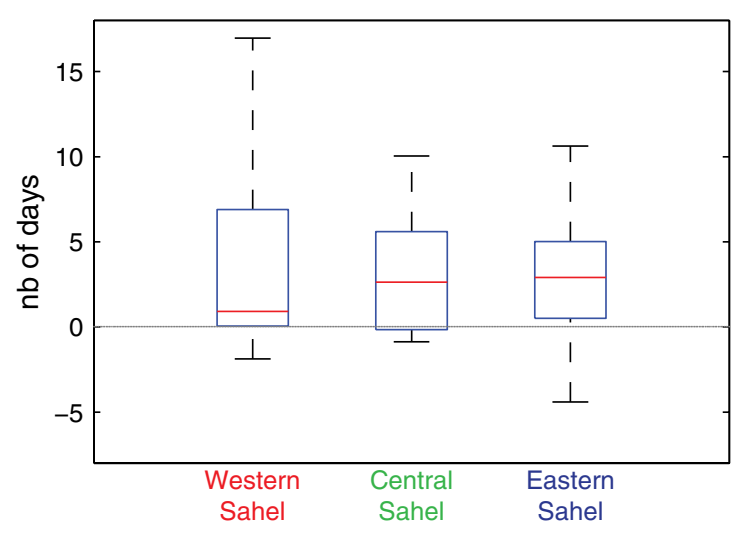

(b)

$$
\text { Demise date change in function of the }
$$
mean SO precipitation change

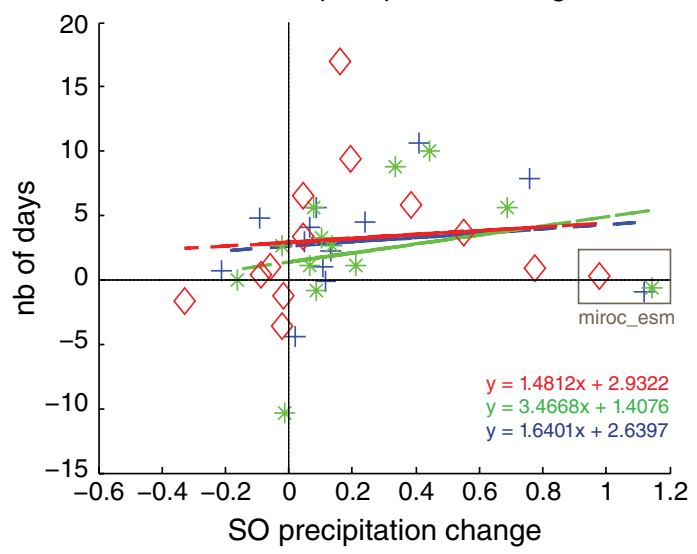

Figure 7. (a) Mean FTR-CTRL demise date change (days) for the western $\left(15^{\circ} \mathrm{W}-0^{\circ} \mathrm{E} ; 10^{\circ}-20^{\circ} \mathrm{N}\right)$, central $\left(10^{\circ} \mathrm{W}-10^{\circ} \mathrm{E} ; 10^{\circ}-20^{\circ} \mathrm{N}\right)$ and eastern $\left(0^{\circ}-25^{\circ} \mathrm{E} ; 10^{\circ}-20^{\circ} \mathrm{N}\right)$ Sahel. The box plot indicates the demise date change median (line), 25 th and 75 th percentile. (b) Demise date change (days) in function of the mean change in precipitation in SO $\left(\mathrm{mm} \mathrm{day}^{-1}\right)$ for the western (pluses), central (stars) and eastern (diamonds) Sahel. Each symbol represents one of the 13 CMIP5 models used.

an increase of $0.3 \mathrm{~mm} \mathrm{day}^{-1}$ ). By this definition, the cessation date of the growing season is found to occur earlier (but with large scatter across models). This is due to a FTR-CTRL potential evapotranspiration increase that is greater or equal to the increase in precipitation.

By this calculation, the delay of the climatological demise date has thus no impact on the cessation date of the growing season and thus on the agricultural activity. Yet, this result is in contradiction with the work of Cook and Vizy (2012), who found a week-long delay in the cessation of the growing season. The discrepancy might result from the different model sensitivities (Cook and Vizy (2012) used one RCM forced with CMIP3 climate change), or from our rather crude representation of potential evapotranspiration changes. Moreover, the start and end of the growing season depend on the specific sensitivity of each crop to temperature, moisture and length of day (for example see Guan et al., 2015). Thus a lot more work is needed to untangle the relationship between seasonal rainfall anomalies, the demise of the monsoon and the cessation of the agricultural rainy season.

\section{Summary and discussion}

We study the projected changes in rainfall and atmospheric circulation in West Africa during the demise months (SO). We focus on the multimodel mean but we choose only one version of each available CMIP5 model to maximize the data independency (as suggested by Masson and Knutti, 2011; Pennell and Reichler, 2011; Knutti et al., 2013). Robustness is measured by the number of models that agree with the sign of the multimodel response. Even for a weaker forcing (a more benign scenario than chosen in most previous CMIP5 studies and looking at the near future), we confirm the future strengthening of the WAM in SO (as described by Biasutti and Sobel, 2009; Wang and Alo, 2012; Biasutti, 2013; Seth et al., 2013).
The mechanisms by which the late-season rainfall increases under global warming differ between the northern and southern Sahel and between September and October. Changes in the monthly mean circulation are especially important for the northern Sahel and during September. Changes in the overall moisture content of the lower troposphere and in local precipitation recycling and evaporation are more important for the southern Sahel and during October. Mid-latitude changes and the increase of the northerlies from the Mediterranean to the Sahel can explain a small part of the rainfall change in SO.

The late season in SO is characterized by a delay of the demise date in the future. It occurs between the middle of September to the beginning of October. The demise starts first in eastern Sahel, then central and western Sahel. There is a weak linear relationship between the delay of the demise date and the precipitation anomalies change in SO. However, for most of the models, a late demise date is associated with higher SO rainfall amounts.

The simulations of the CMIP5 atmosphere-oceangeneral circulation model (AOGCM) are marred by several biases due to the models' coarse resolution and a drastic underestimation of regional orography. The present results should be confirmed with RCMs and global GCM simulations using finer grids. This will allow better simulations, for example, of the Mediterranean moisture source but also of wind changes due to small scale processes and better representation of the strong gradients in atmosphere-land fluxes and moisture recycling. It is however crucial to use consistent physical packages between the RCM and the forcing GCM (Saini et al., 2015). Otherwise the downscaled field will not be the result of the forcing field with a higher resolution but mainly to a change of the parameterization.

Furthermore, the CMIP5 AOGCM simulations used in this study do not take into account the vegetation and land use evolutions. The precipitation-vegetation feedback could have a considerable impact on the sub-Saharan 
region (Douville et al., 2001; Paeth and Thamm, 2007; Paeth et al., 2009; Wang and Alo, 2012). Adding land use and vegetation evolutions could allow more accurate future projections and may lead to a stronger increase of rainfall amounts during the last months of the monsoon period through positive feedbacks: more rainfall amounts are associated with more vegetation cover and thus more water recycling.

\section{Acknowledgements}

We acknowledge the World Climate Research Programme's Working Group on Coupled Modelling, which is responsible for CMIP, and we thank the climate modelling groups for producing and making available their model output. For CMIP, the U.S. Department of Energy's Program for Climate Model Diagnosis and Intercomparison provides coordinating support and led development of software infrastructure in partnership with the Global Organization for Earth System Science Portals. Calculations were performed using HPC resources from DSI-CCUB (Université de Bourgogne). We acknowledge three anonymous reviewers for their relevant input.

\section{References}

Bentsen M, Bethke I, Debernard J, Iversen T, Kirkevåg A, Seland $\varnothing$, Drange H, Roelandt C, Seierstad I, Hoose C. 2012. The Norwegian earth system model, NorESM1-M-Part 1: description and basic evaluation. Geosci. Model Dev. 5: 2843-2931, doi: 10.5194/gmdd-5-2843-2012.

Biasutti M. 2013. Forced Sahel rainfall trends in the CMIP5 archive. J. Geophys. Res. Atmos. 118: 1613-1623, doi: 10.1002/jgrd.50206.

Biasutti M, Sobel AH. 2009. Delayed Sahel rainfall and global seasonal cycle in a warmer climate. Geophys. Res. Lett. 36: L23707, doi: $10.1029 / 2009 \mathrm{gl} 041303$.

Caniaux G, Giordani H, Redelsperger J-L, Guichard F, Key E, Wade M. 2011. Coupling between the Atlantic cold tongue and the West African monsoon in boreal spring and summer. J. Geophys. Res. Oceans 116: C04003, doi: 10.1029/2010JC006570.

Chylek P, Li J, Dubey M, Wang M, Lesins G. 2011. Observed and model simulated 20th century Arctic temperature variability: Canadian earth system model CanESM2. Atmos. Chem. Phys. Discuss. 11: 22893-22907, doi: 10.5194/acpd-11-22893-2011.

Collins W, Bellouin N, Doutriaux-Boucher M, Gedney N, Halloran P, Hinton T, Hughes J, Jones C, Joshi M, Liddicoat S. 2011. Development and evaluation of an Earth-system model-HadGEM2. Geosci. Model Dev. 4: 1051-1075, doi: 10.5194/gmd-4-1051-2011.

Cook KH, Vizy EK. 2012. Impact of climate change on mid-twenty-first century growing seasons in Africa. Clim. Dyn. 39: 2937-2955, doi: 10.1007/s00382-012-1324-1.

Cook BI, Smerdon JE, Seager R, Coats S. 2014. Global warming and 21st century drying. Clim. Dyn. 43: 2607-2627, doi: 10.1007/s00382-014-2075-y.

Douville H, Chauvin F, Broqua H. 2001. Influence of soil moisture on the Asian and African Monsoons. Part I: mean monsoon and daily precipitation. J. Clim. 14: 2381-2403, doi: 10.1175/1520-0442(2001)014<2381:iosmot >2.0.co;2.

Dufresne J-L, Foujols M-A, Denvil S, Caubel A, Marti O, Aumont O, Balkanski Y, Bekki S, Bellenger H, Benshila R. 2013. Climate change projections using the IPSL-CM5 Earth System Model: from CMIP3 to CMIP5. Clim. Dyn. 40: 2123-2165, doi: 10.1007/s00382-012-1636-1.

Dunne JP, John JG, Adcroft AJ, Griffies SM, Hallberg RW, Shevliakova E, Stouffer RJ, Cooke W, Dunne KA, Harrison MJ. 2012. GFDL's ESM2 global coupled climate-carbon Earth System Models. Part I: physical formulation and baseline simulation characteristics. J. Clim. 25: 6646-6665, doi: 10.1175/JCLI-D-11-00560.1.
Fontaine B, Louvet S. 2006. Sudan-Sahel rainfall onset: definition of an objective index, types of years, and experimental hindcasts. J. Geophys. Res. Atmos. 111: D20103, doi: 10.1029/2005JD007019.

Fontaine B, Roucou P, Monerie P-A. 2011. Changes in the African monsoon region at medium-term time horizon using 12 AR4 coupled models under the A1b emissions scenario. Atmos. Sci. Lett. 12: 83-88, doi: 10.1002/asl.321

Gleckler PJ, Taylor KE, Doutriaux C. 2008. Performance metrics for climate models. J. Geophys. Res. Atmos. 113: D06104, doi: 10.1029/2007JD008972.

Grist JP, Nicholson SE. 2001. A study of the dynamic factors influencing the rainfall variability in the west african sahel. J. Clim. 14: $1337-1359$, doi: 10.1175/1520-0442(2001)014<1337:ASOTDF $>2.0 . \mathrm{C} 0 ; 2$.

Grist JP, Josey SA, Marsh R, Good SA, Coward AC, De Cuevas BA, Alderson SG, New AL, Madec G. 2010. The roles of surface heat flux and ocean heat transport convergence in determining Atlantic Ocean temperature variability. Ocean Dyn. 60: 771-790.

Guan K, Sultan B, Biasutti M, Baron C, Lobell DB. 2015. What aspects of future rainfall changes matter for crop yields in West Africa? Geophys. Res. Lett. 42: 8001-8010.

Haarsma RJ, Selten FM, Weber SL, Kliphuis M. 2005. Sahel rainfall variability and response to greenhouse warming. Geophys. Res. Lett. 32: L17702, doi: 10.1029/2005GL023232.

Hagos SM, Cook KH. 2007. Dynamics of the west african monsoon jump. J. Clim. 20: 5264-5284, doi: 10.1175/2007JCLI1533.1.

Hoerling M, Hurrell J, Eischeid J, Phillips A. 2006. Detection and attribution of twentieth-century northern and southern african rainfall change. J. Clim. 19: 3989-4008, doi: 10.1175/JCLI3842.1.

James R, Washington R, Jones R. 2015. Process-based assessment of an ensemble of climate projections for West Africa. J. Geophys. Res. Atmos. 120: 1221-1238, doi: 10.1002/2014JD022513.

Kitoh A, Endo H, Krishna Kumar K, Cavalcanti IFA, Goswami P, Zhou T. 2013. Monsoons in a changing world: a regional perspective in a global context. J. Geophys. Res. Atmos. 118: 3053-3065, doi: $10.1002 /$ jgrd.50258.

Knutti R, Furrer R, Tebaldi C, Cermak J, Meehl GA. 2010. Challenges in combining projections from multiple climate models. J. Clim. 23: 2739-2758, doi: 10.1175/2009JCLI3361.1.

Knutti R, Masson D, Gettelman A. 2013. Climate model genealogy: generation CMIP5 and how we got there. Geophys. Res. Lett. 40: 1194-1199.

Kröger J, Busalacchi AJ, Ballabrera-Poy J, Malanotte-Rizzoli P. 2005. Decadal variability of shallow cells and equatorial sea surface temperature in a numerical model of the Atlantic. J. Geophys. Res. Oceans 110: $\mathrm{C} 12003$.

Lambert SJ, Boer GJ. 2001. CMIP1 evaluation and intercomparison of coupled climate models. Clim. Dyn. 17: 83-106, doi: 10.1007/PL00013736.

Lavaysse C, Flamant C, Janicot S, Parker D, Lafore J-P, Sultan B, Pelon J. 2009. Seasonal evolution of the West African heat low: a climatological perspective. Clim. Dyn. 33: 313-330, doi: 10.1007/s00382-009-0553-4.

Lebel T, Ali A. 2009. Recent trends in the Central and Western Sahel rainfall regime (1990-2007). J. Hydrol. 375: 52-64, doi: 10.1016/j.jhydrol.2008.11.030.

Lee J-Y, Wang B. 2014. Future change of global monsoon in the CMIP5 Clim. Dyn. 42: 101-119, doi: 10.1007/s00382-012-1564-0.

Liebmann B, Bladé I, Kiladis GN, Carvalho LM, Senay GB, Allured D, Leroux S, Funk C. 2012. Seasonality of African precipitation from 1996 to 2009. J. Clim. 25: 4304-4322, doi: 10.1175/JCLI-D-11-00157.1.

Lodoun T, Giannini A, Traoré PS, Somé L, Sanon M, Vaksmann M, Rasolodimby JM. 2013. Changes in seasonal descriptors of precipitation in Burkina Faso associated with late 20th century drought and recovery in West Africa. Environ. Dev. 5: 96-108, doi: 10.1016/j.envdev.2012.11.010.

Louvet S, Fontaine B, Roucou P. 2003. Active phases and pauses during the installation of the West African monsoon through 5-day CMAP rainfall data (1979-2001). Geophys. Res. Lett. 30: 2271, doi: 10.1029/2003GL018058.

Masson D, Knutti R. 2011. Climate model genealogy. Geophys. Res. Lett. 38: L08703, doi: 10.1029/2011GL046864.

Maynard KM, Royer JFR, Chauvin FC. 2002. Impact of greenhouse warming on the West African summer monsoon. Clim. Dyn. 19: 499-514, doi: 10.1007/s00382-002-0242-z.

Meinshausen M, Smith SJ, Calvin K, Daniel JS, Kainuma M, Lamarque J, Matsumoto K, Montzka S, Raper S, Riahi K. 2011. The RCP 
greenhouse gas concentrations and their extensions from 1765 to 2300 . Clim. Change 109: 213-241, doi: 10.1007/s10584-011-0156-z.

Monerie P-A, Fontaine B, Roucou P. 2012. Expected future changes in the African monsoon between 2030 and 2070 using some CMIP3 and CMIP5 models under a medium-low RCP scenario. J. Geophys. Res. Atmos. 117: D16111, doi: 10.1029/2012JD017510.

Monerie P-A, Roucou P, Fontaine B. 2013. Mid-century effects of climate change on African monsoon dynamics using the A1B emission scenario. Int. J. Climatol. 33: 881-896, doi: 10.1002/joc.3476.

Nicholson S. 2005. On the question of the "recovery" of the rains in the West African Sahel. J. Arid Environ. 63: 615-641, doi: 10.1016/j.jaridenv.2005.03.004.

Nie J, Boos WR, Kuang Z. 2010. Observational evaluation of a convective quasi-equilibrium view of monsoons. J. Clim. 23: 4416-4428.

Okumura Y, Xie S-P. 2004. Interaction of the Atlantic equatorial cold tongue and the African monsoon. J. Clim. 17: 3589-3602, doi: 10.1175/1520-0442(2004)017<3589:IOTAEC > 2.0.CO; 2.

Paeth H, Thamm H-P. 2007. Regional modelling of future African climate north of $15 \mathrm{~S}$ including greenhouse warming and land degradation. Clim. Change 83: 401-427, doi: 10.1007/s10584-006-9235-y.

Paeth H, Born K, Girmes R, Podzun R, Jacob D. 2009. Regional climate change in tropical and northern Africa due to greenhouse forcing and land use changes. J. Clim. 22: 114-132, doi: 10.1175/2008JCLI2390.1.

Park J-Y, Bader J, Matei D. 2015. Northern-hemispheric differential warming is the key to understanding the discrepancies in the projected Sahel rainfall. Nature communications 6: 5985, doi: $10.1038 /$ ncomms6985.

Pennell C, Reichler T. 2011. On the effective number of climate models. J. Clim. 24: 2358-2367, doi: 10.1175/2010JCLI3814.1.

Phillips TJ, Gleckler PJ. 2006. Evaluation of continental precipitation in 20th century climate simulations: the utility of multimodel statistics. Water Resour. Res. 42: W03202, doi: 10.1029/2005WR004313.

Pierce DW, Barnett TP, Santer BD, Gleckler PJ. 2009. Selecting globa climate models for regional climate change studies. Proc. Natl. Acad. Sci. 106: 8441-8446, doi: 10.1073/pnas.0900094106.

Pincus R, Batstone CP, Hofmann RJP, Taylor KE, Glecker PJ. 2008. Evaluating the present-day simulation of clouds, precipitation, and radiation in climate models. J. Geophys. Res. Atmos. 113: D14209, doi: 10.1073/pnas.0900094106

Randall DA, Wood RA, Bony S, Colman R, Fichefet T, Fyfe J, Kattsov V, Pitman A, Shukla J, Srinivasan J, Stouffer RJ, Sumi A, Taylor KE. 2007. Climate models and their evaluation. In Climate Change 2007: The physical science basis. Contribution of Working Group I to the Fourth Assessment Report of the Intergovernmental Panel on Climate Change. Cambridge University Press: Cambridge, UK and New York, NY.

Reichler T, Kim J. 2008. How well do coupled models simulate today's climate? Bull. Am. Meteorol. Soc. 89: 303-311, doi: 10.1175/BAMS-89-3-303.

Richter I, Xie S-P. 2008. On the origin of equatorial Atlantic biases in coupled general circulation models. Clim. Dyn. 31: 587-598, doi: $10.1007 / \mathrm{s} 00382-008-0364-\mathrm{z}$

Rogelj J, Meinshausen M, Knutti R. 2012. Global warming under old and new scenarios using IPCC climate sensitivity range estimates. Nat. Clim. Change 2: 248-253, doi: 10.1038/nclimate1385.

Rotstayn LD, Collier MA, Dix MR, Feng Y, Gordon HB, O'Farrell SP, Smith IN, Syktus J. 2010. Improved simulation of Australian climate and ENSO-related rainfall variability in a global climate model with an interactive aerosol treatment. Int. J. Climatol. 30: 1067-1088, doi: $10.1002 /$ joc. 1952.

Saini R, Wang G, Yu M, Kim J. 2015. Comparison of RCM and GCM projections of boreal summer precipitation over Africa. J. Geophys. Res. Atmos. 120: 3679-3699, doi: 10.1002/2014JD022599.

Sanogo S, Fink AH, Omotosho JA, Ba A, Redl R, Ermert V. 2015 Spatio-temporal characteristics of the recent rainfall recovery in West Africa. Int. J. Climatol. 35: 4589-4605, doi: 10.1002/joc.4309.

Santer BD, Taylor KE, Gleckler PJ, Bonfils C, Barnett TP, Pierce DW, Wigley TML, Mears C, Wentz FJ, Brüggemann W, Gillett NP, Klein SA, Solomon S, Stott PA, Wehner MF. 2009. Incorporating model quality information in climate change detection and attribution studies. Proc. Natl. Acad. Sci. 106: 14778-14783.

Scheff J, Frierson DM. 2014. Scaling potential evapotranspiration with greenhouse warming. J. Clim. 27: 1539-1558, doi: 10.1175/JCLI-D-13-00233.1.

Seager R, Naik N, Vecchi GA. 2010. Thermodynamic and dynamic mechanisms for large-scale changes in the hydrological cycle in response to global warming. J. Clim. 23: 4651-4668, doi: 10.1175/2010JCLI3655.1.

Servain J, Caniaux G, Kouadio YK, McPhaden MJ, Araujo M. 2014. Recent climatic trends in the tropical Atlantic. Clim. Dyn. 43: 3071-3089.

Seth A, Rauscher SA, Biasutti M, Giannini A, Camargo SJ, Rojas M. 2013. CMIP5 projected changes in the annual cycle of precipitation in monsoon regions. J. Clim. 26: 7328-7351, doi: 10.1175/JCLI-D-12-00726.1.

Shindell DT, Pechony O, Faluvegi GS, Voulgarakis A, Nazarenko LS, Lamarque J, Bowman K, Milly G, Kovari W, Ruedy R. 2013. Interactive ozone and methane chemistry in GISS-E2 historical and future climate simulations. Atmos. Chem. Phys. 13: 2653-2689, doi: 10.7916/D82V2DZJ.

Sultan B, Janicot S. 2000. Abrupt shift of the ITCZ over West Africa and intra-seasonal variability. Geophys. Res. Lett. 27: 3353-3356, doi: 10.1029/1999GL011285.

Sultan B, Janicot S. 2003. The West African monsoon dynamics. Part II: the "preonset" and "onset" of the summer monsoon. $J$. Clim. 16: 3407-3427, doi: 10.1175/1520-0442(2003)016<3407: TWAMDP>2.0.CO;2.

Taylor KE, Stouffer RJ, Meehl GA. 2012. An overview of CMIP5 and the experiment design. Bull. Am. Meteorol. Soc. 93: 485-498, doi: 10.1175/BAMS-D-11-00094.1.

Thomson AM, Calvin KV, Smith SJ, Kyle GP, Volke A, Patel P, Delgado-Arias S, Bond-Lamberty B, Wise MA, Clarke LE. 2011. RCP4.5: a pathway for stabilization of radiative forcing by 2100. Clim. Change 109: 77-94, doi: 10.1007/s10584-011-0151-4.

Trenberth KE, Stepaniak DP, Caron JM. 2000. The global monsoon as seen through the divergent atmospheric circulation. J. Clim. 13: 3969-3993, doi: 10.1175/1520-0442(2000)013<3969:TGMAST> 2.0.CO;2.

Villamayor J, Mohino E. 2015. Robust Sahel drought due to the Interdecadal Pacific Oscillation in CMIP5 simulations. Geophys. Res. Lett. 42: 1214-1222.

Vizy EK, Cook KH. 2012. Mid-twenty-first-century changes in extreme events over northern and tropical Africa. J. Clim. 25: $5748-5767$

Vizy EK, Cook KH, Crétat J, Neupane N. 2013. Projections of a wetter Sahel in the twenty-first century from global and regional models. $J$. Clim. 26: 4664-4687.

Voldoire A, Sanchez-Gomez E, Mélia DS, Decharme B, Cassou C, Sénési S, Valcke S, Beau I, Alias A, Chevallier M. 2013. The CNRM-CM5. 1 global climate model: description and basic evaluation. Clim. Dyn. 40: 2091-2121, doi: 10.1007/s00382-011-1259-y.

Volodin E, Dianskii N, Gusev A. 2010. Simulating present-day climate with the INMCM4.0 coupled model of the atmospheric and oceanic general circulations. Izvestiya. Atmos. Oceanic Phys. 46: 414-431, doi: $10.1134 / \mathrm{S} 000143381004002 \mathrm{X}$.

Wang G, Alo CA. 2012. Changes in precipitation seasonality in West Africa predicted by RegCM3 and the impact of dynamic vegetation feedback. Int. J. Geophys. 2012: 597205, doi: 10.1155/2012/ 597205.

Watanabe S, Hajima T, Sudo K, Nagashima T, Takcmura T, Okajima H, Nozawa T, Kawase H, Abe M, Yokohata T. 2011. MIROC-ESM 2010: model description and basic results of CMIP 5-20c3m experiments. Geosci. Model Dev. 4: 845-872, doi: 10.5194/gmd-4-845-2011.

Webster PJ, Magafla V, Palmer T, Shukla J, Tomas R, Yanai M, Yasunari T. 1998. Monsoons: processes, predictability, and the prospects for prediction. J. Geophys. Res. 103: 14451-14510.

Xiao-Ge X, Tong-Wen W, Jiang-Long L, Zai-Zhi W, Wei-Ping L, Fang-Hua W. 2012. How well does BCC_CSM1.1 reproduce the 20th century climate change over China? Atmos. Oceanic Sci. Lett. 6: $21-26$.

Yin JH. 2005. A consistent poleward shift of the storm tracks in simulations of 21 st century climate. Geophys. Res. Lett. 32: L18701, doi: 10.1029/2005GL023684.

Yukimoto S, Adachi Y, Hosaka M, Sakami T, Yoshimura H, Hirabara M, Tanaka TY, Shindo E, Tsujino H, Deushi M. 2012. A new global climate model of the Meteorological Research Institute: MRI-CGCM3 - model description and basic performance. $J$. Meteorol. Soc. Jpn. 90: 23-64.

Zhang G, Cook KH. 2014. West African monsoon demise: climatology, interannual variations, and relationship to seasonal rainfall. J. Geophys. Res. Atmos. 119: 10,175-110,193, doi: 10.1002/ 2014JD022043. 